\title{
DESIGN OF LONG SPAN BRIDGES AND HIGH RISE BUILDINGS IN THE TWENTY-FIRST CENTURY
}

\author{
S. HERNANDEZ \\ School of Civil Engineering, University of Coruña, Spain.
}

\begin{abstract}
Long span bridges and high rise buildings are two types of structures that have always arisen the attention of engineers and architects. The former are appropriate for creating crossings over wide rivers or estuaries in a sort of recreation of the geography of our planet. The latter are many times used to be a symbol of the wealthy of the cities where they are erected.

Construction of both typologies has experienced a dramatic activity since the last decades of the past century in many countries located in different continents such as Europe, Asia or America, and such tendency has even increased in recent years, and several challenging proposals have also been proposed for the years to come.

This article starts with a brief description of the capabilities and advantages of long span bridges and tall buildings. Afterwards, a description of the main realizations of suspension and cable-stayed bridges already existing all around the world is presented mentioning their main characteristics and features. Additionally, information on bridge projects that could take place in a near future are mentioned. Then, a similar treatment is carried out for the vast collection of signature buildings erected in the last decades. It will be observed that in addition to the new tall structures in already very cosmopolitan cities, many of them have been built in other places and have transformed radically the skyline of cities in China, Singapore, Korea or the Arabic Gulf countries, to name a few.

Keywords: long span bridges, structural design, structural typologies, tall buildings.
\end{abstract}

\section{INTRODUCTION}

Structural analysis has been always a fertile field of activity and research amongst engineers and architects and usually some innovations intended for a specific field is later on useful in other disciplines.

Amongst all structural typologies, bridges and buildings have always captured the attention of practitioners and also some academics have written about the conceptual design and the circumstances that surrounded the definition and construction of these classes of structures. Studies by Blockley [1], Graf [2], Billington [3], Heinly and Leonhardt [4] and Escrig [5] are brilliant examples of this literature.

In fact, since the last decades of the previous century, the design, construction and planning of long span bridges and high rise buildings have experienced a spectacular flourishing. Challenging bridges have been built spanning wide estuaries and straits around the world, and ever increasing tall buildings with unusual shapes have appeared in several countries. It seems that even in the context of increasing economical crisis, this trend is going to continue in the future, so more achievements can be expected. In the following paragraphs, a description of the already made works and the initiatives under planning will be presented for these two structural typologies.

\section{RECENT PAST, PRESENT AND FUTURE OF LONG SPAN BRIDGES}

After the Verrazano bridge opened in 1964 with its world record of $1289 \mathrm{~m}$ of main span, no new bridge had been built challenging such impressive design. But everything started to change when the bridge over the Humber bridge in Northern England was built in 1981 and 
its $1410 \mathrm{~m}$ of main span surpassed the mentioned New York Bridge. Similarly in France at the estuary of the Seine River, the Normandy bridge, with $856 \mathrm{~m}$ of main span inaugurated the era of very long span cable-stayed bridges. These structures appear in Figures 1 and 2.

Most part of the increasing activity in the construction of long span bridges started in the 1980s of the 20th century. At that time, Japan started three links between Honshu and Shikoku islands crossing the Seto Sea that required a vast collection of bridges as shown in Figure 3a. Amongst them, the Tatara cable-stayed bridge had $890 \mathrm{~m}$ of span length and the suspension Akashi bridge reached $1991 \mathrm{~m}$ in the central span; both constituted world records in bridges of their class and are presented in Figures $3 \mathrm{~b}$ and $3 \mathrm{c}$.

At the same time, Danish government was involved in the initiative of finishing the connections between its main islands and also creating a link with Sweden as described in Figure 4a. That purpose required crossing the Great Belt, between the Islands of Funen and Zealand and also spanning the Oresund strait between Zealand island and Sweden. Both proposals led to the Great Belt suspension bridge with $1624 \mathrm{~m}$ of main span and the cablestayed Oresund bridge which are shown in Figures $4 \mathrm{~b}$ and $4 \mathrm{c}$.

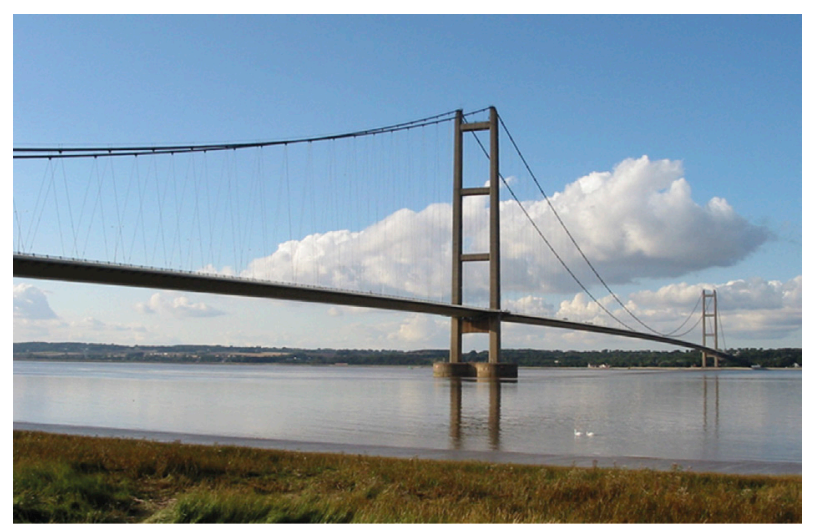

Figure 1: Humber Bridge.

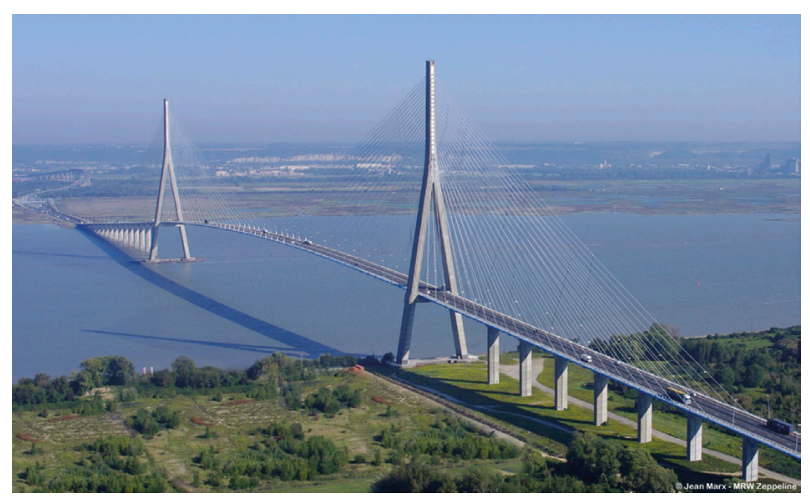

Figure 2: Normandy Bridge. 


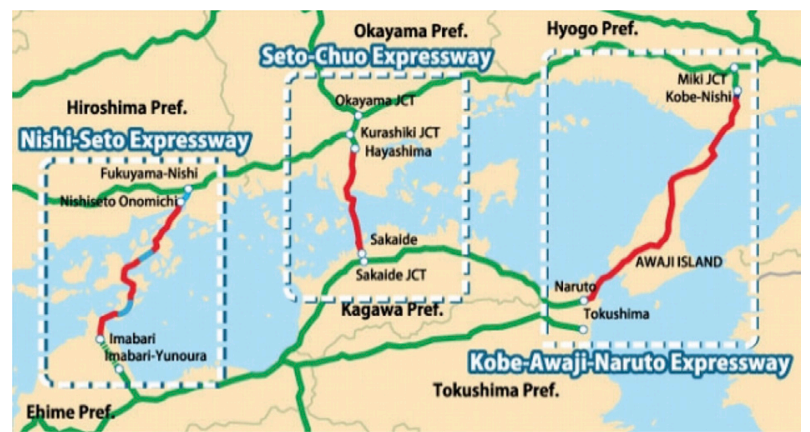

a) Honshu-Sikoku routes

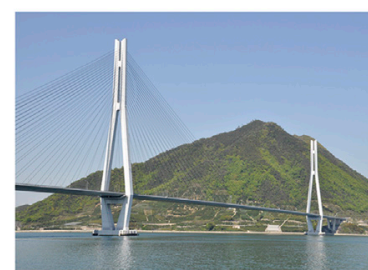

b) Tatara bridge

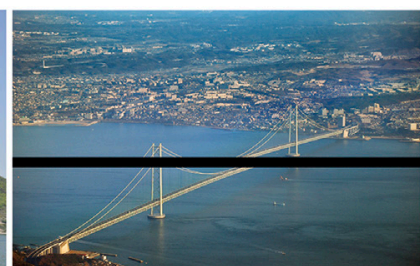

c) Akashi bridge

Figure 3: Honshu-Sikoku routes and relevant bridges

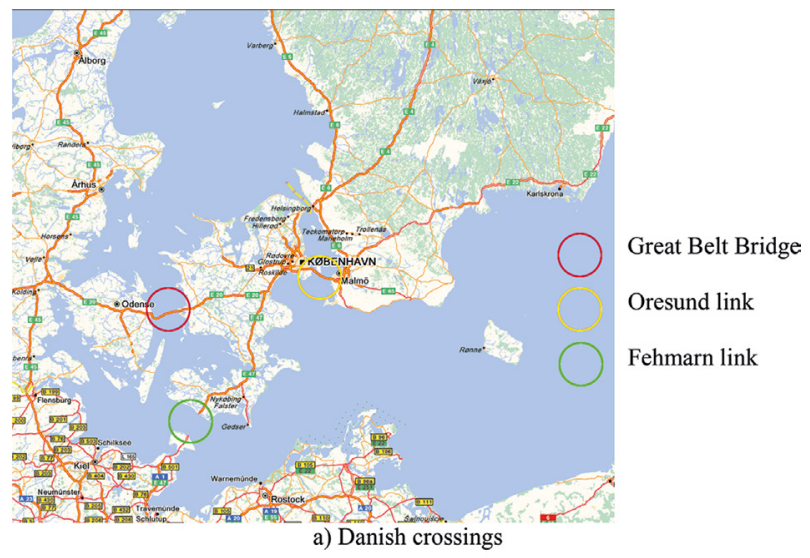

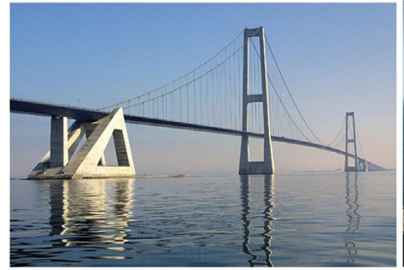

b) Great Belt bridge

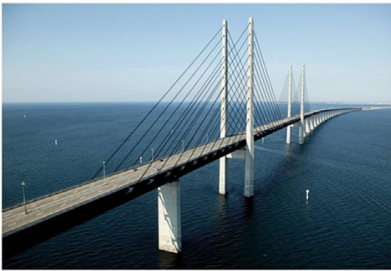

c) Oresund bridge

Figure 4: Danish long span bridges. 
In the meanwhile activity translated mostly to Hong-Kong. In that regard, the Tsing Ma bridge, carrying car and train traffic and the Ting Kau, a multispan cable-stayed bridge, were built in 1997 and 1998, respectively, in the former British colony and can be seen in Figures 5 and 6.

The start of the new millennium brought a number of projects in both sides of the Pacific Ocean. On the Asian part, China opened a saga of ever increasing long span bridges crossing the Yangtse and other rivers. Amongst them, the Runyang bridge and the Xihoumen suspension bridges having central span lengths of 1490 and $1650 \mathrm{~m}$, respectively, are the most relevant realizations. Also, the Taizhou bridge was the first suspension bridge with two main spans, in this case of $1080 \mathrm{~m}$ of length and were proofs of the capacity of Chinese civil engineers. As for cable-stayed bridges, the Edong, Stonecutters and Sutong bridges reached lengths of 926, 1018 and $1088 \mathrm{~m}$ of main span, respectively. In the latter case, it generated a new world record surpassing the aforementioned Tatara Bridge. These bridges are presented in Figures 7 and 8.

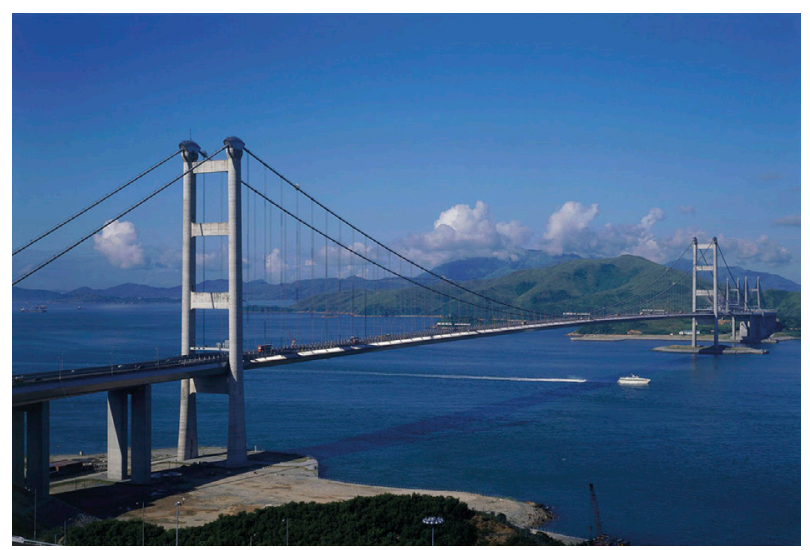

Figure 5: Tsing Ma bridge.

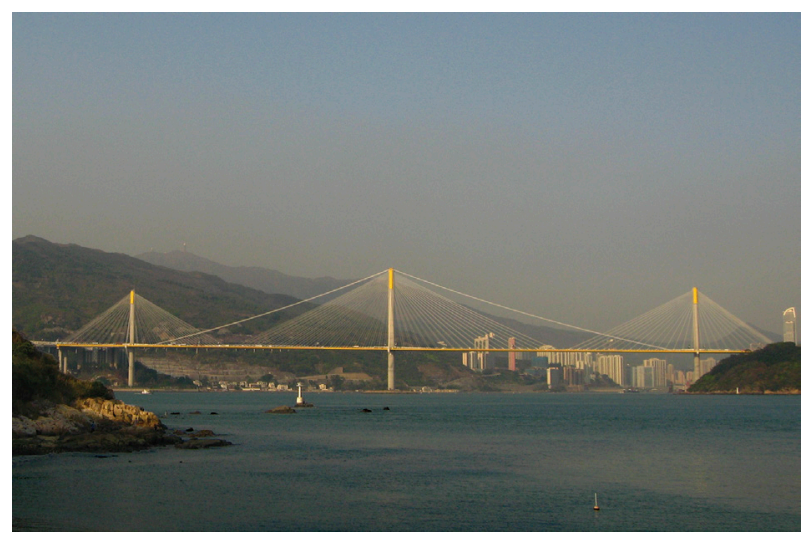

Figure 6: Ting Kau bridge. 


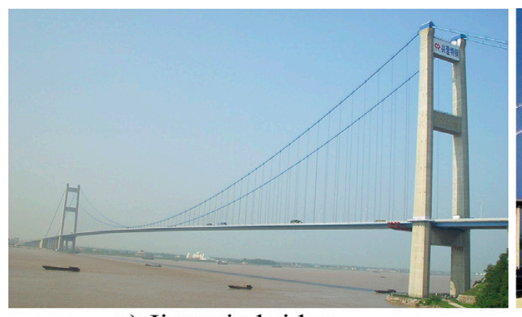

a) Jiangyin bridge

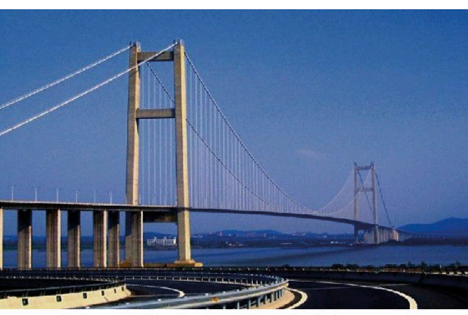

b) Runyang bridge

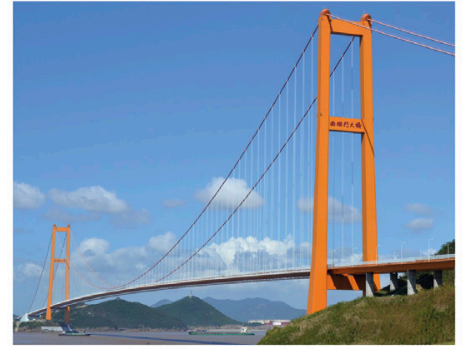

c) Xihoumen bridge

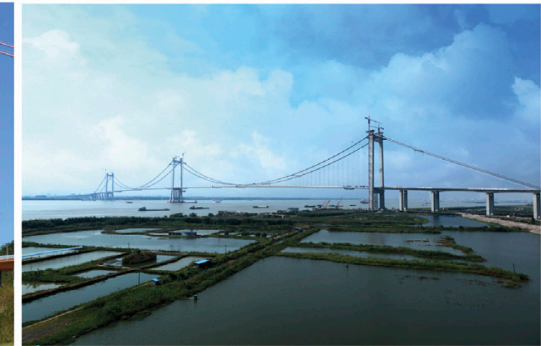

d) Taizhou bridge

Figure 7: Suspension bridges in China.

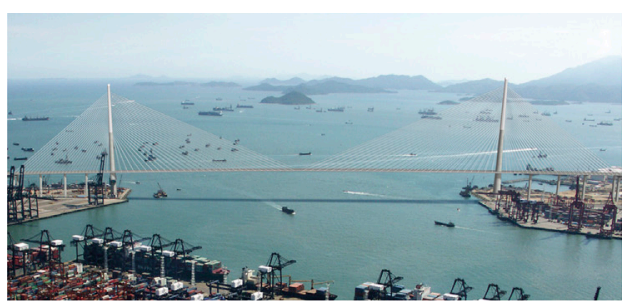

a) Stonecutters bridge

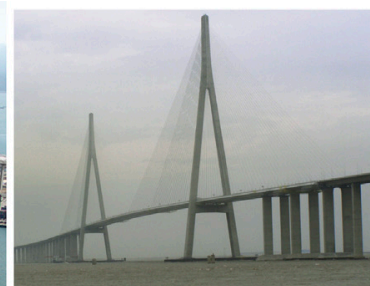

b) Sutong bridge

Figure 8: Cable-stayed bridges in China.

Additionally, it is worthy to mention the efforts of Korea for joining the club of nations erecting this class of challenging structures. In that regard, the cable-stayed Incheon bridge was finished in 2009 having $800 \mathrm{~m}$ of central span length and the Yi Sun-Sin suspension bridge with 1545 of central span opened in 2012 and are presented in Fig. 9.

Russia, which had no new long span bridges since long time ago built one recently in the year 2012 named the Russky Island bridge in Vladivostok, shown in Fig. 10. Overcoming weather inclemencies and geographical difficulties, a cable-stayed bridge of $3100 \mathrm{~m}$ of total length and a main span of 1104 m was inaugurated in the Pacific coast of Russia. Such span length placed this structure as the longest of its category. The opening was scheduled for the date of the 2012 Asian-Pacific Economic Cooperation Leaders meeting and everything run on time for the ceremony even before such event.

On the opposite side of the Pacific Ocean, the metropolitan area of San Francisco needed a solution for the eastern part of the San Francisco-Oakland bridge that resulted in damage during the 1989 Loma Prieta earthquake. The winning design was a cable suspension bridge 


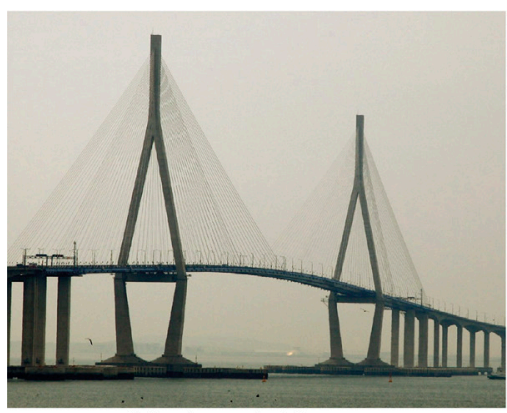

a) Incheon bridge

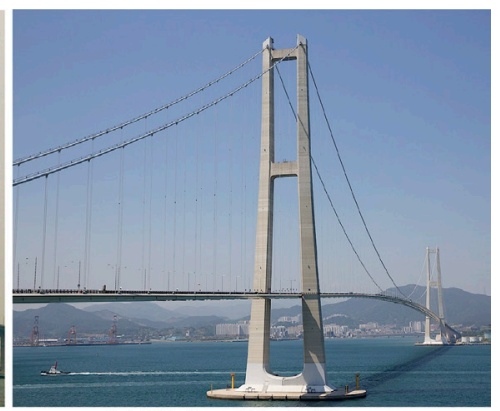

b) Yi Sun-Sin bridge

Figure 9: Long span bridges in South Korea.

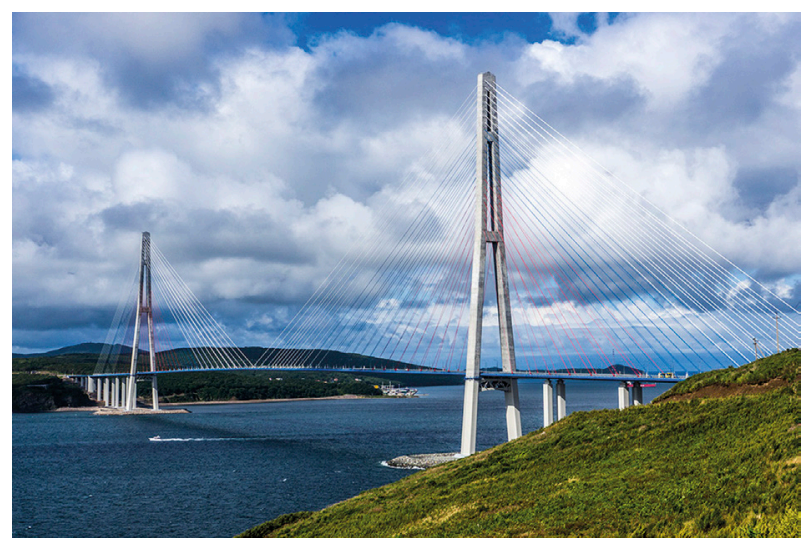

Figure 10: Russky Island bridge.

with several new features as it had a single tower supporting two spans with 3D main cable configuration and the main cable was self-anchored around the bridge deck, so no anchorage blocks were needed. The bridge was opened in September 2013 and is presented in Fig. 11.

In Europe, the concept of continuous or multispan cable-stayed bridge, already developed by the Swiss engineer Christian Menn sometime ago, acquired momentum and two examples of this typology were built at the beginning of the new millennium. In France, the Millau viaduct, in a motorway connecting Paris with the Mediterranean Sea was opened in 2001. It consisted in a eight-span cable-stayed bridge over the Tarn river with an average span of about $300 \mathrm{~m}$ and very tall towers reaching up to $340 \mathrm{~m}$ altitude. In Greece, months before the inauguration day of the Olympic Games of 2004, a bridge crossing the western corner of the Corinthos gulf was finished. It received the name of Rion-Antirion bridge and was designed to undergo very high seismic loads as its location is in an area with severe earthquake risks. It is divided into five spans with $3 \mathrm{D}$ concrete towers and very strong columns almost submerged into the gulf waters. Figures 12 and 13 contains a view of such structures. 


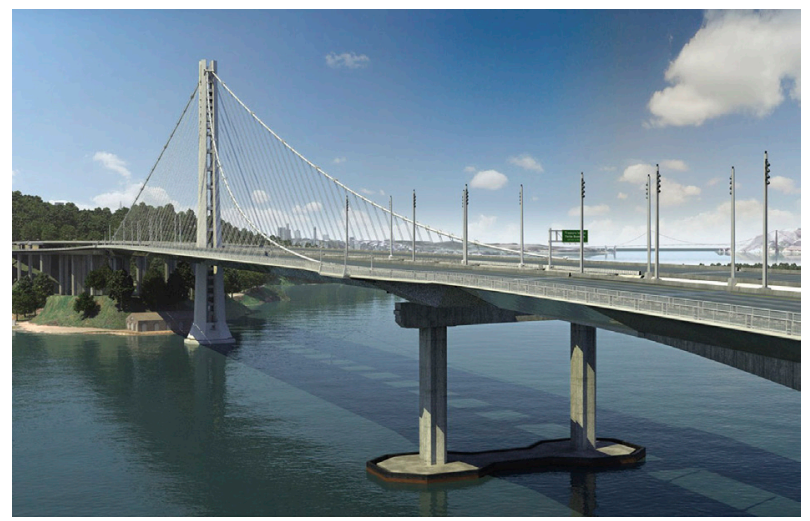

Figure 11: New Bay bridge.

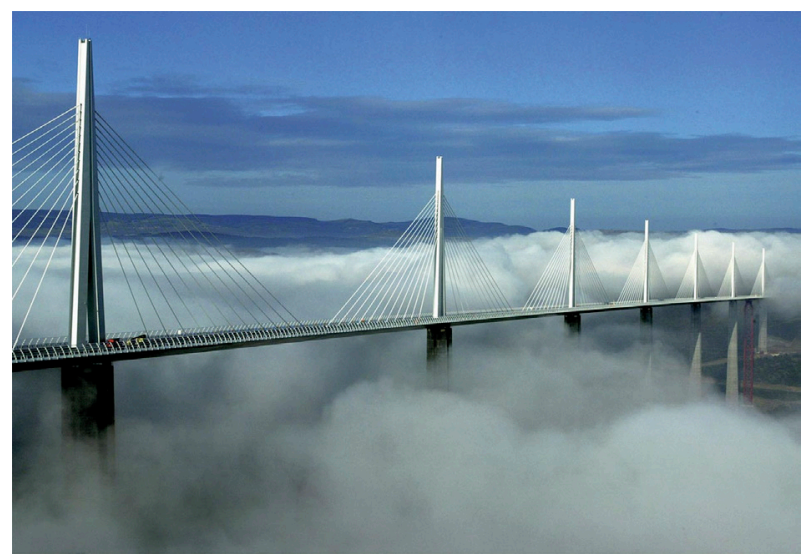

Figure 12: Millau viaduct (France).

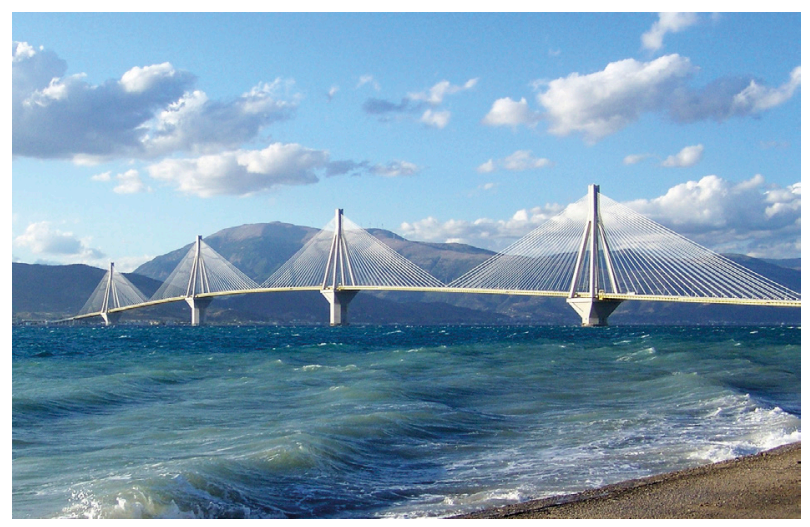

Figure 13: Rion-Antirion bridge (Greece). 
Nowadays, several brilliant designs of long span bridges are under construction in Europe and South America. Namely, in Turkey, two structures shown in Fig. 14, are currently built, in the case of the Itmiz bridge, a suspension bridge located in the eastern side of the sea of Marmara, with a central span of 1551 m works started in 2013 and in Istambul, the third crossing over the Bosphorus Strait, coined as Yavuz Sultan Selim bridge, a hybrid suspension and cable-stayed bridge, is also under construction since 2013.

In UK, the Firth of Forth in Scotland will count shortly with a new bridge over it. After the Cantilever bridge of 19th century for railway traffic and the suspension bridge built about 50 years ago dedicated to motor vehicles, a new multispan cable-stayed bridge is currently built and it is currently referred as Queensferry Crossing. It is composed of four mainspans having $650 \mathrm{~m}$ length with the two central ones. Very slender towers of pole shape produce a very aesthetic configuration.

Very far away, in South America, the Chilean government has decided to start the construction of a bridge joining the mainland and the Chiloe island crossing the Chacao Channel. The project requires a continuous suspension bridge with two central spans of more than $1000 \mathrm{~m}$ similar to the Taizhou bridge in China. The bridge is located in a region prone to strong earthquakes and in fact it was affected by the Valdivia seism, in 1960. It is worth noting that it reached 9.5-point in the Richter scale, being the highest earthquake ever recorded. The Chacao bridge will have the central tower upon Roca Remolinos, a reef located in the central part of the strait. Both bridges are presented in Figures 15 and 16.

The list of works described before shows the advanced capabilities of engineering design and construction techniques reached in civil engineering. Nevertheless, there is always room for more challenging projects and some others challenging structures have chance to be built in the future. Recently and after the incorporation of Crimea to Russia, the government of this country has announced the decision of building a bridge over the Kerch strait and thus creating a fixed link between the Crimean peninsula and mainland Russia.

In Denmark after the Oresund link connecting this country with Sweden, another link is planned to provide a connection with Germany at the Fehmarn strait. Two alternatives, namely a bridge and a tunnel have been proposed, and although so far the tunnel is the current decision the battle perhaps is not lost for the bridge that was designed as a multispan cablestayed bridge.

In the northeast corner of Spain, a route coined as ERA2000 [6] has been proposed to cross the area of the estuaries between the cities of A Coruña and Ferrol. It involves three bridges of which the West and Central are two suspension structures of about $2000 \mathrm{~m}$ of central span,

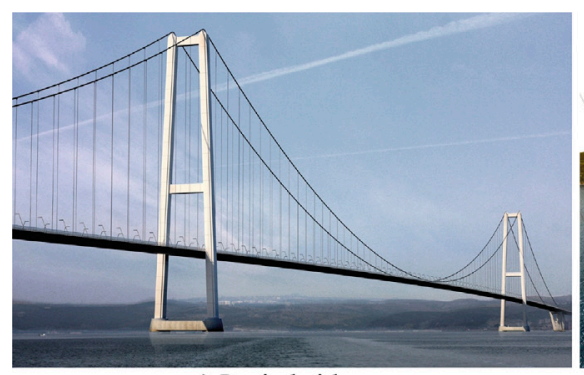

a) Itmiz bridge

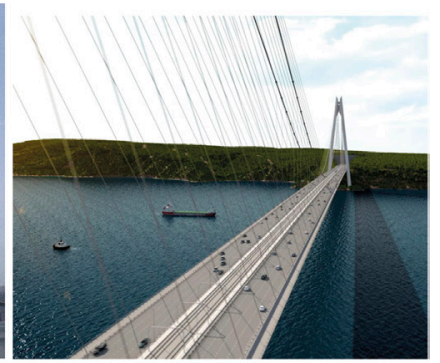

b) Yavuz Sultan Selim bridge

Figure 14: Bridges under construction in Turkey. 


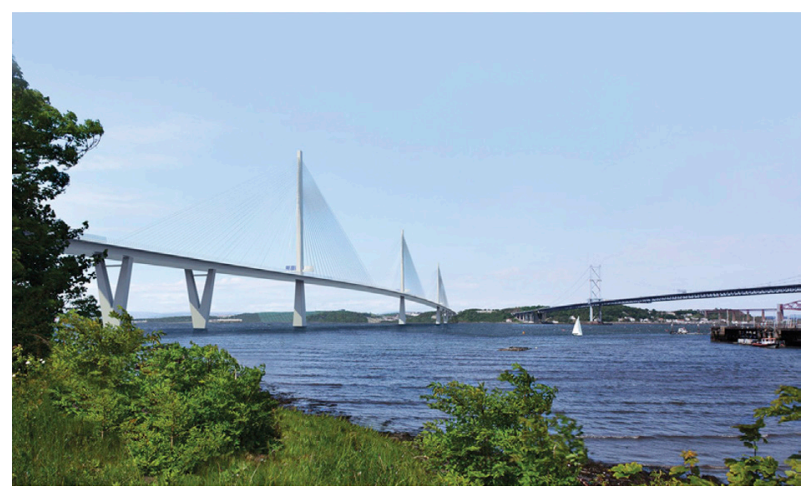

Figure 15: Queensferry Crossing (UK).

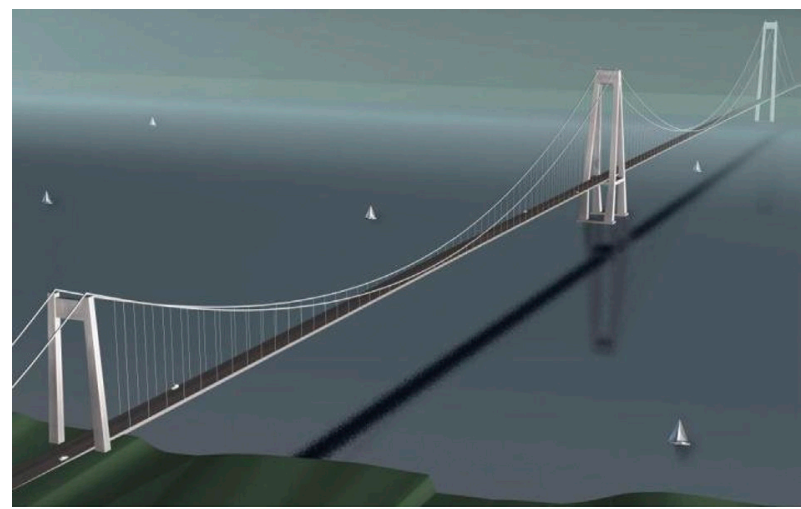

Figure 16: Chacao bridge (Chile).

while the East bridge is projected as an bowstring arch. A computer generated image of two bridges of this proposal re shown in Figure 17.

In Italy, in the Messina strait, that separates the island of Sicily from mainland, a suspension bridge has been completely designed and the competition for building it was carried out a few years ago. That construction will end the traditional isolation of Sicily, an island of about $26,000 \mathrm{~km}^{2}$, larger than some European countries and with more than five millions of inhabitants. The bridge will allocate both trains and car traffic and thus creating a fixed link between the island and mainland Italy according to the 21st century. Nevertheless, when everything was arranged to start working political changes in the Italian government stopped the construction and currently the project is in standby. The proposed bridge is a magnificent structure with a deck composed by three box girders connected by transversal beams analysed according to the most up to date capabilities of structural engineering and contains a main span of $3300 \mathrm{~m}$. The bridge has been projected to safely undergo high level earthquakes and wind speed of $270 \mathrm{~km} / \mathrm{h}$. Some graphic information on this bridge appears in Fig. 18.

All aforementioned bridges and the ambitious proposals for the near future have been designed using the latest capabilities on aeroelastic analysis, both experimental and compu- 


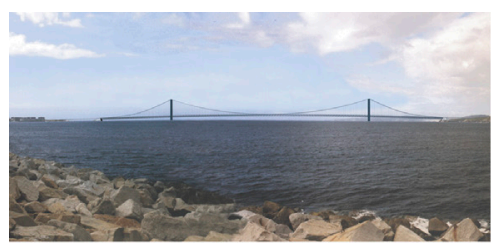

a) West bridge

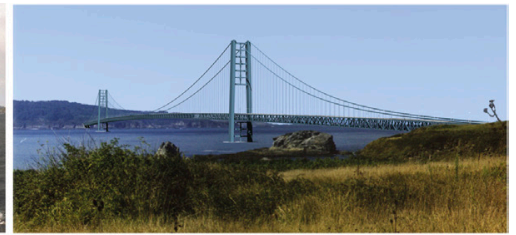

b) Central bridge

Figure 17: Bridges in the ERA2000 project.

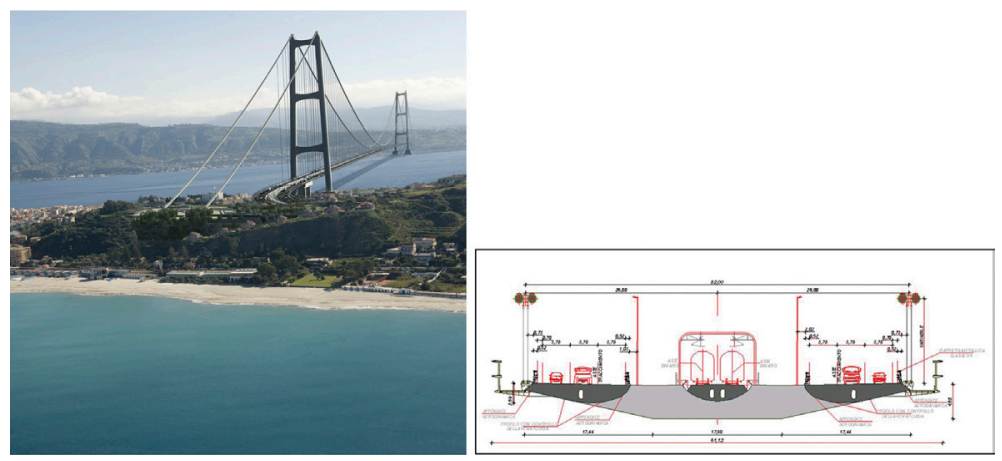

Figure 18: Messina strait bridge.

tational, that allow to understand the behaviour of such structures under wind flow. Well-known experts Simiu and Scanlan [7], Gimsing [8], Jurado et al. [9] and Svensson [10] have authored books describing the existing methodologies.

\section{SIGNATURE BUILDINGS: RECENT PAST AND PRESENT}

High rise buildings have also been always a typology that rose the attention of architects and structural engineers. An antecedent could be found in the Mile High Illinois building intended to be 1600-m tall proposed by Frank Lloyd Wright [11] time ago. Commonly, these signature constructions have been used as a representation of economical power or a sign of distinction by their owners. They were a way of creating a difference from their competitors. Thus, it is not strange that each time a city becomes an important financial centre several tall buildings are erected.

This class of structures allows freedom of design to architects because wind forces are not a crucial issue as it is in long span bridges. Earthquakes can be a worry for high rise buildings but the advances in sophisticated devices for foundations as double or triple pendulum friction bearings help the structure to release the seism energy and give the designers the possibility of creating tall constructions even in earthquake prone locations.

Accordingly, a vast variety of conceptual designs, different in shape, configuration and external aspect have been built.

It can be said that this tendency started in the last quarter of the 20th century when an architectural movement coined high tech architecture took place. It liked to create buildings showing clearly the structural system that usually was even external, as a skeleton. Perhaps the most representative works of this period are the Pompidou Centre in París and the Headquarters of the HSBC in Hong-Kong, finished in 1977 and 1979, respectively and presented in Figures 19 and 20. 


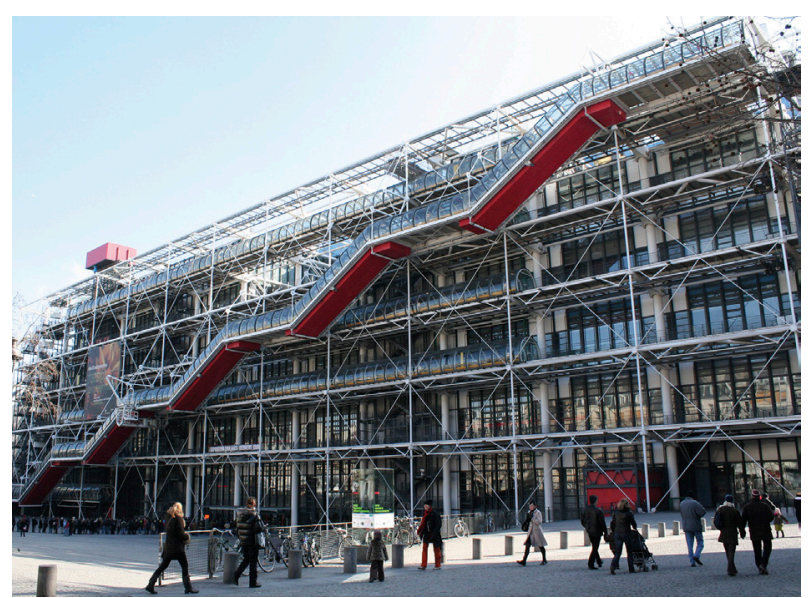

Figure 19: Pompidou Centre, Paris.

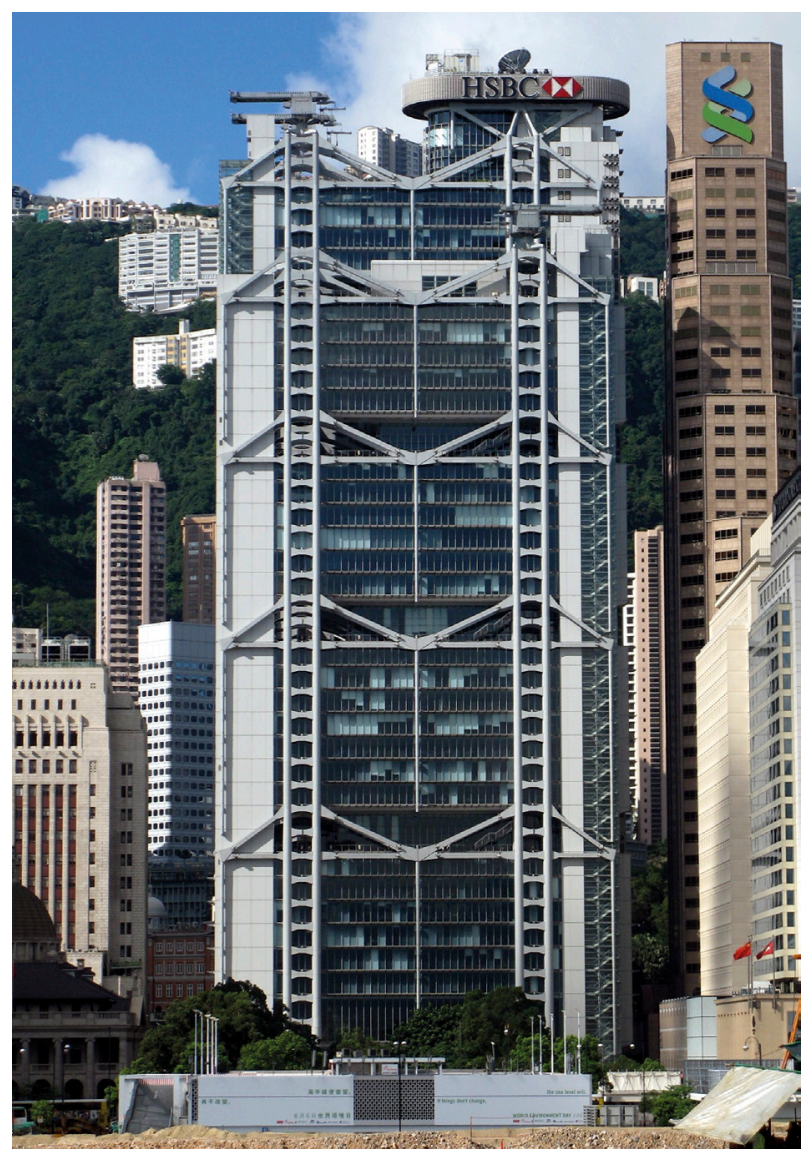

Figure 20: HSBC building, Hong-Kong. 
The spectacular economical growing in the Pacific Rim in the last decades of the XX century led to the flourishing of innovative designs in the main cities. Amongst them, Hong-Kong was an important financial and communication centre and, therefore, a collection of signature construction was built. Fig. 21 shows the skyline of the city and two main realizations of challenging structures.

Similarly, the state city of Singapore and Kuala Lumpur, the city capital of Malaysia, became two places where many international corporations established important delegations and set up offices and luxury resorts. A view of the skyline of these cities appear in Fig. 22 and some representative buildings appear in Fig. 23.

South Korea experienced a great transformation in the last third of the past century. Its economy changed radically becoming an industrial power with very competitive companies in car, construction, heavy machinery and shipbuilding sectors. Such economical success led to the construction of important infrastructures and the transformation of the city capital, Seoul, in a very modern city. Two examples of innovative buildings are next shown in Fig. 24.

A similar example can be found in Taiwan. Its capital city, Taipei, was the place for the erection of very creative high rise constructions that showed different approaches of modern architecture. Amongst them, two examples deserve some explanation: the Taipei 101, named because it has 101 floors with a delicate geometry that resembles to some extent a trunk of bamboo, it has some vegetal aspect. On the other side, the headquarters of the China Steel Corporation is a building with in a very unusual shape with acute angles. Both buildings can be observed in Fig. 25.

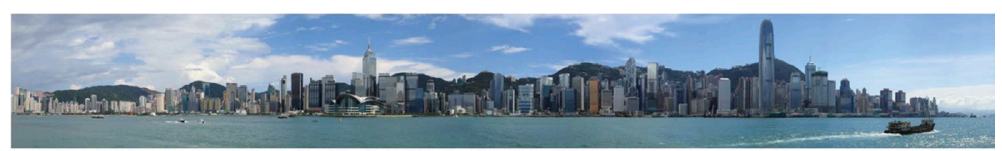

a) Hong-Kong skyline

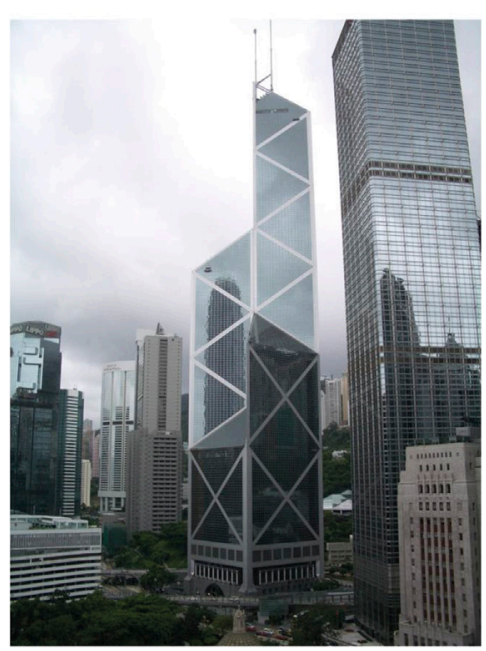

b) Bank of China build. (315m), 1990

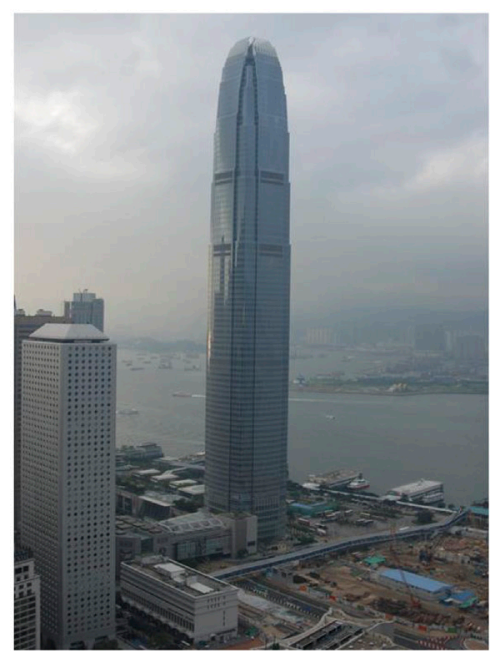

c) IFC (414 m), 2003

Figure 21: Hong-Kong skyline and some buildings. 


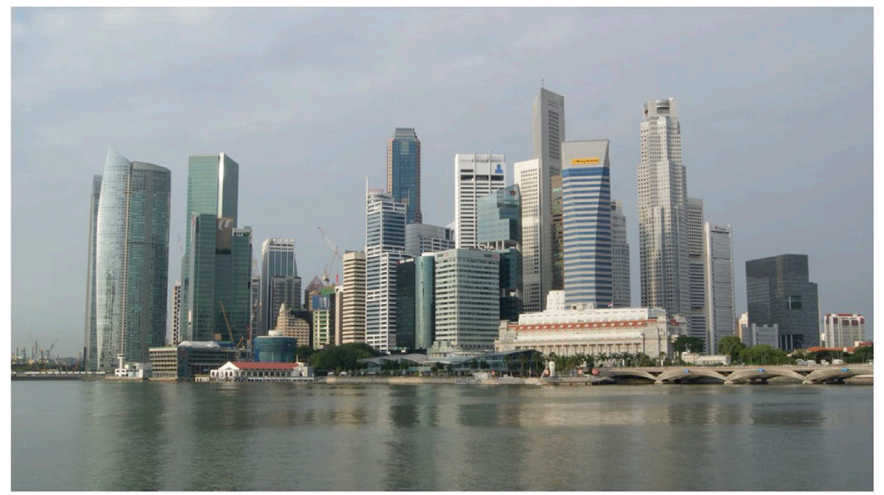

a) Singapore skyline

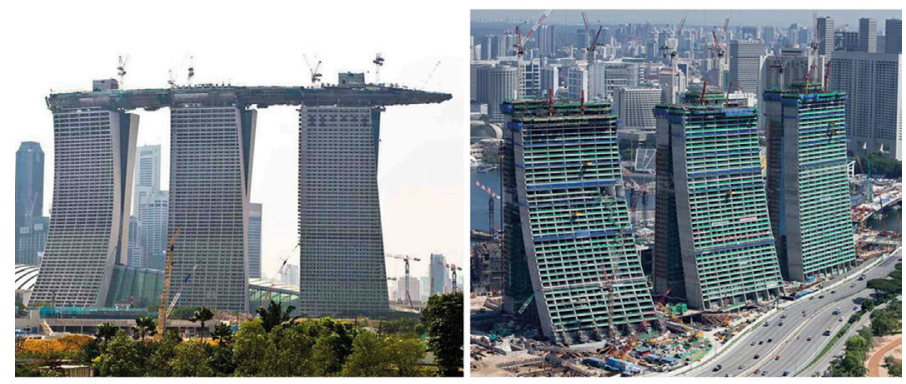

b) Las Vegas Sands

Figure 22: Singapore skyline and some buildings.

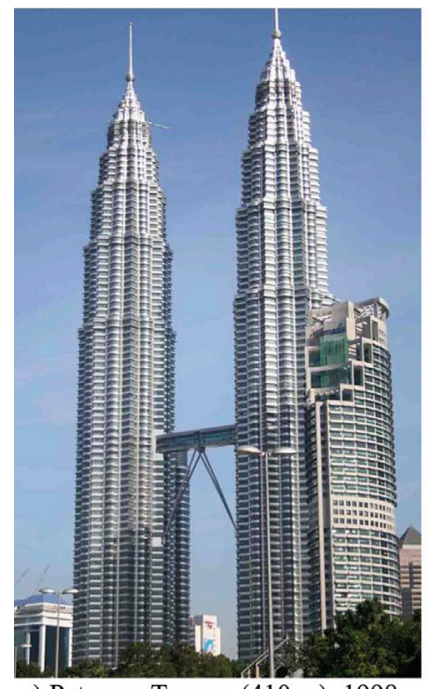

a) Petronas Towers (410 m), 1998

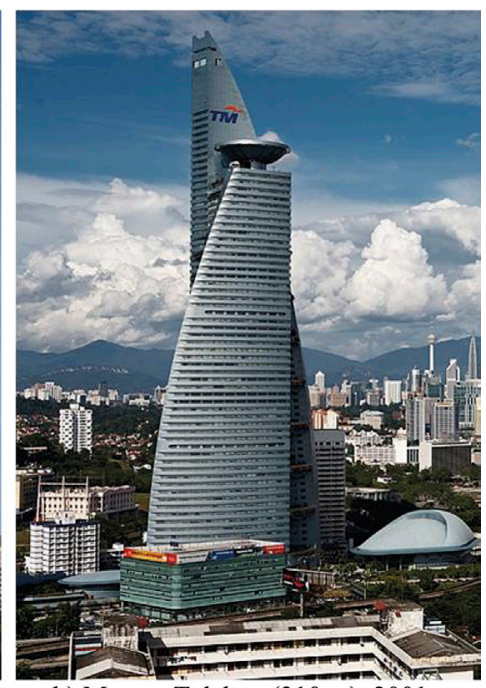

b) Menara Telekon (310 m), 2001

Figure 23: Kuala Lumpur buildings. 


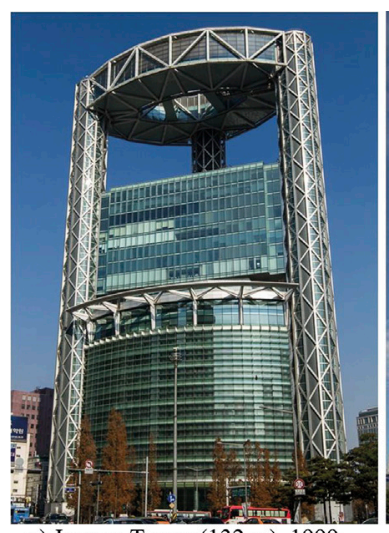

a) Jongno Tower (132 m), 1999

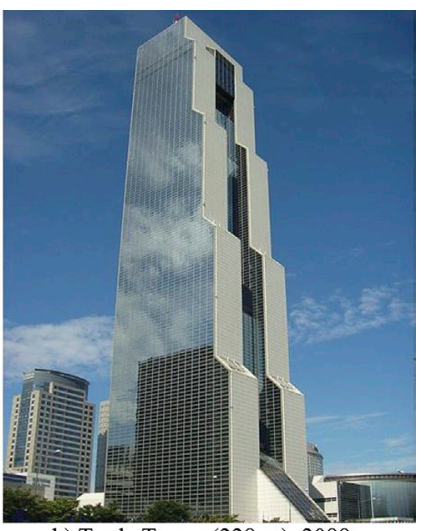

b) Trade Tower $(228 \mathrm{~m}), 2088$

Figure 24: Innovative buildings in Seoul.

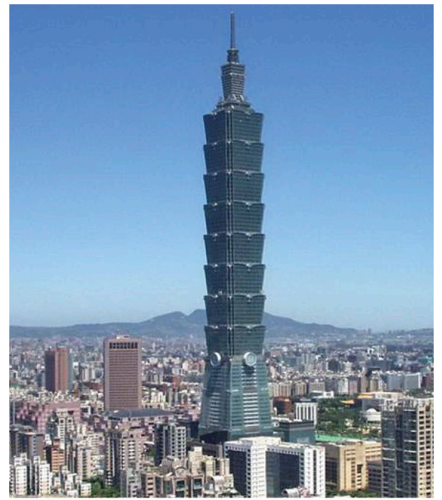

a) Taipei $101(509 \mathrm{~m}), 2004$

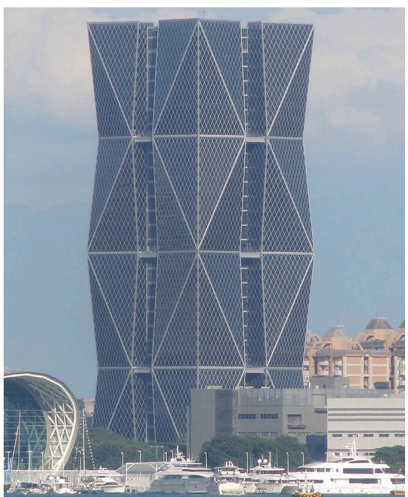

b) China Steel Corporation (195 m), 2088

Figure 25: Innovative buildings in Taipei.

In mainland China, several cities have established themselves as important locations for universities, industries and financial firms. Just to name a few the capital city Beijing, Shanghai, Tianjin, Chongqing, Guanghou, Dalian or Nanjing. Accordingly, a collection of examples of contemporary architecture can be found in their new neighbourhoods and are presented in Figures 26 to 30.

One of the most impressive changes in city planning in recent times is the fast and spectacular urbanization appeared in the Arabic Gulf countries. Emirates such as Dubai, Abu Dhabi and Qatar have been created in a couple of decades and have been the ever faster fantastic cities from the point of view of modern architecture, and consultancy firms compete to offer new creations for high rise buildings than including curved shapes, complex geometries and 


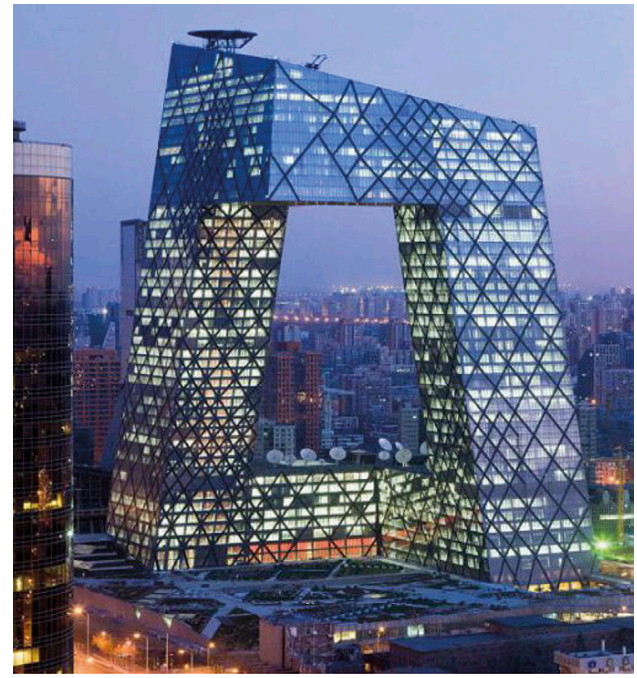

Figure 26: CCTV in Beijing (234 m), 2008.

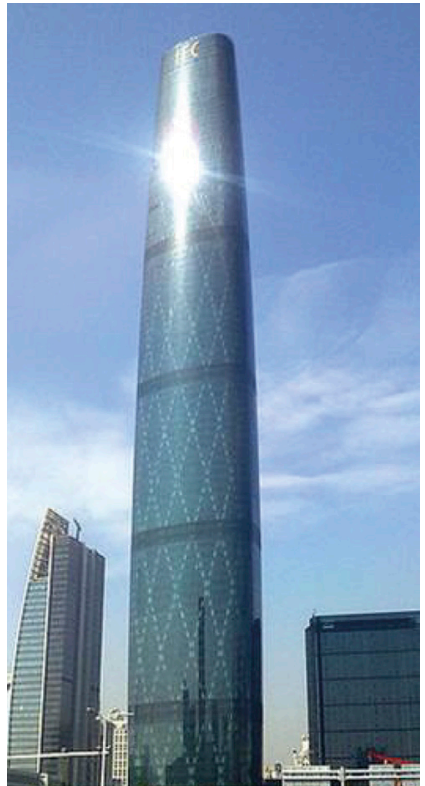

Figure 27: IFC in Guanghou (443 m), 2010. 


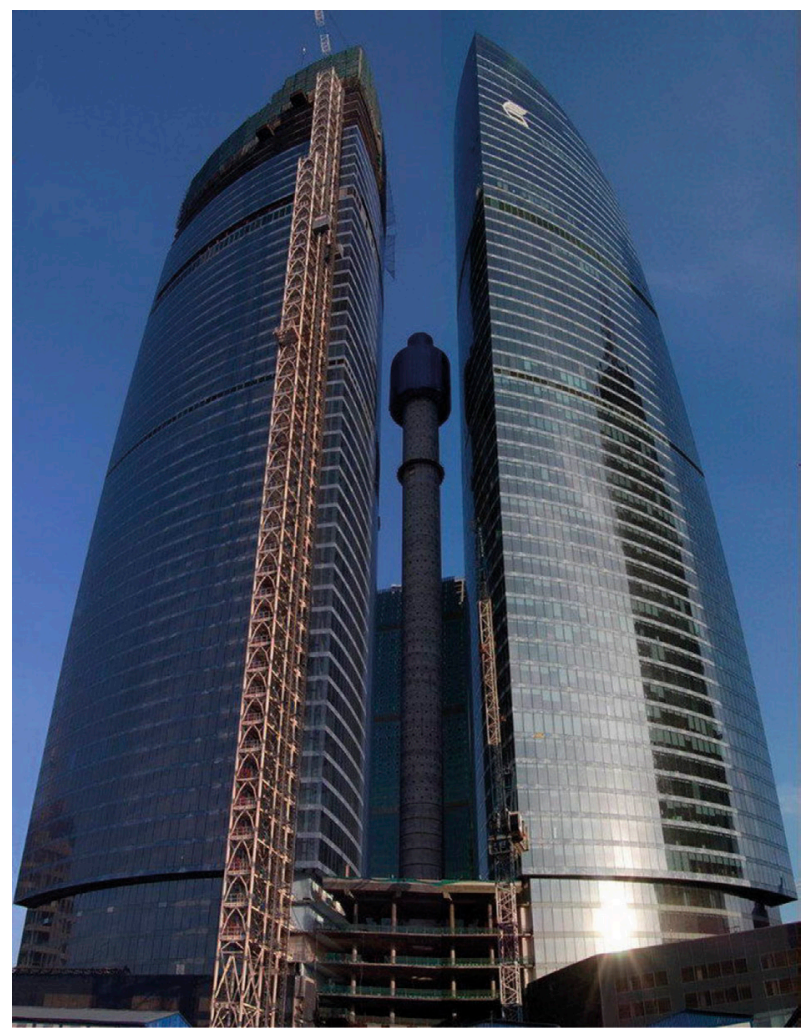

Figure 28: Eton Centre, Dalian (383 m), 2015.

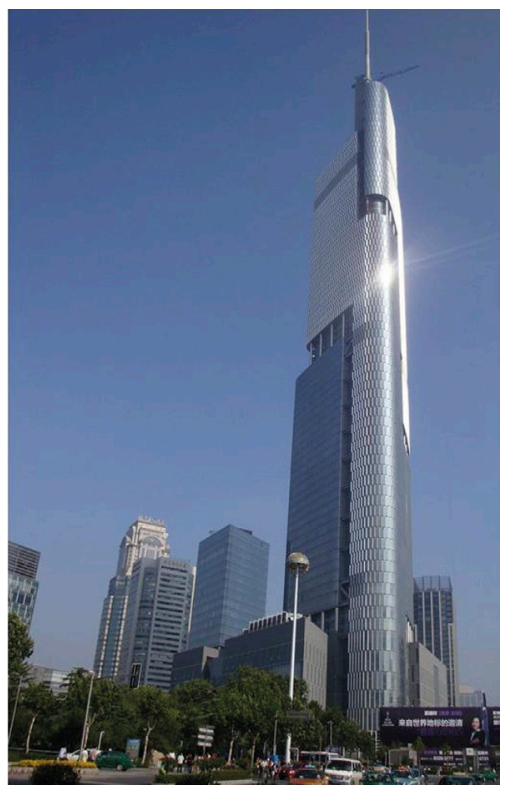

Figure 29: Zifeng Tower, Nanjing (381 m), 2010. 


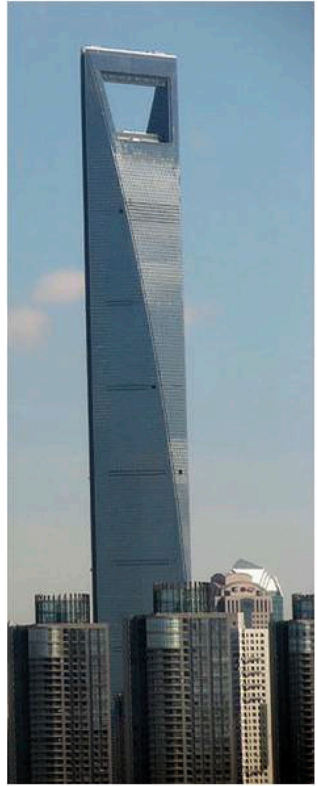

a) WTC (492 m), 2007

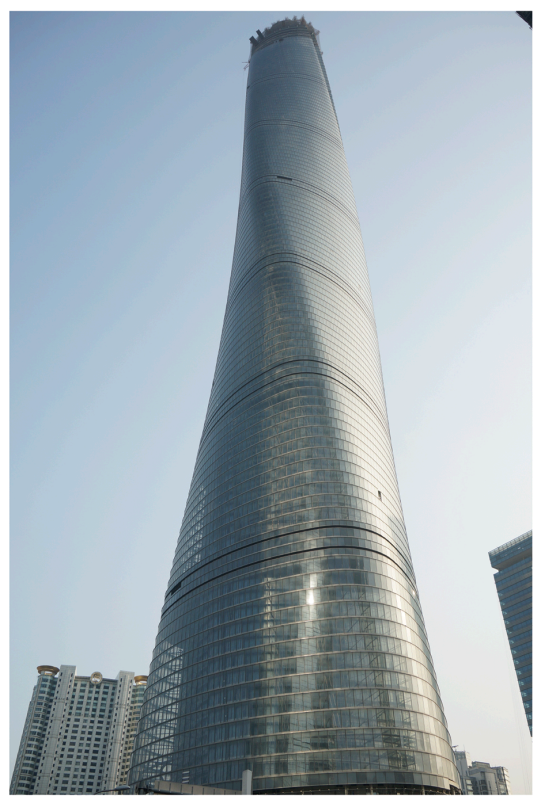

b) Shanghai tower (632 m), 201

Figure 30: High rise buildings in Shanghai.

intricate configurations to obtain the victory in the competitions. Some examples of the most recent designs are shown in the Figures 31 to 33.

Other well-known cities by their architectural tradition have added new pieces to their already brilliant heritage. Amongst them New York that inaugurated the Beekman Tower in 2011 and rebuilt the area of the former World Trade Center with new constructions finished in 2014 as can be seen in Fig. 34.

London is another example of the mixture of historical monuments and innovative designs. The Swiss Re building with its bullet-like shape and The Shard, both shown in Figure 35 and located near the Thames river, are examples of the expressivity of contemporary architecture.

More examples can be found in Italy, namely in Milan with the Diamond Tower or in Malmoe with the vertical twisting shape of the Turning Torso building that are presented in Figures 36 and 37.

Several outstanding realizations can also be found in Spain, mainly in Madrid, Barcelona and touristic cities in the Mediterranean Sea. In the city capital of Spain, the inclined buildings of Puerta de Europa (Europe Gate) were finished in 1996 and have appeared in several movies. Recently, a building for the central offices of the Gas Natural company and a set of four tall buildings have been erected in the northern financial area of the city. In Barcelona, an example of high tech architecture was designed by the Olympic Games of 1992 to allocate the Hotel des Arts and recently other Spanish cities as Bilbao or Zaragoza have incorporated new iconic buildings in recent years. In the former case the Guggenheim Museum provided the opportunity to create an unusual design and in the latter case a World Exhibition gave way for several architectural concepts and amongst them the one coined the Torre del Agua (The 


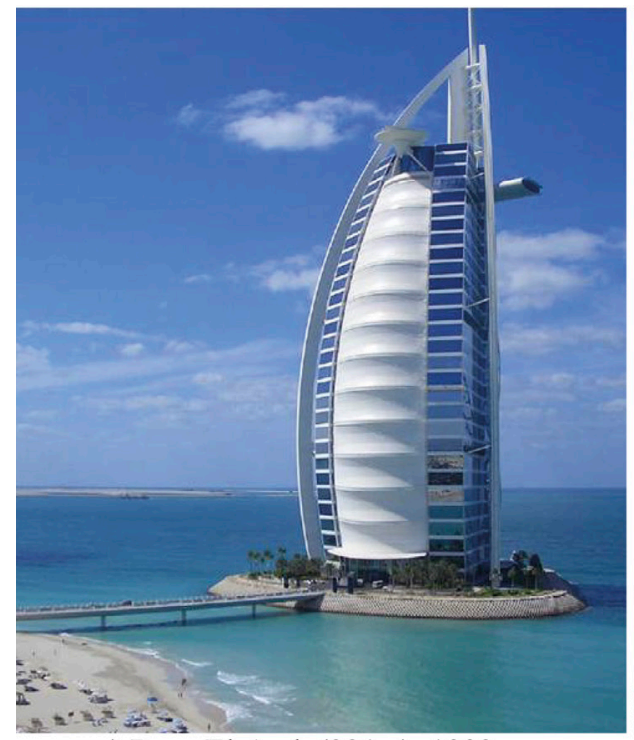

a) Burg-El-Arab (321m), 1999

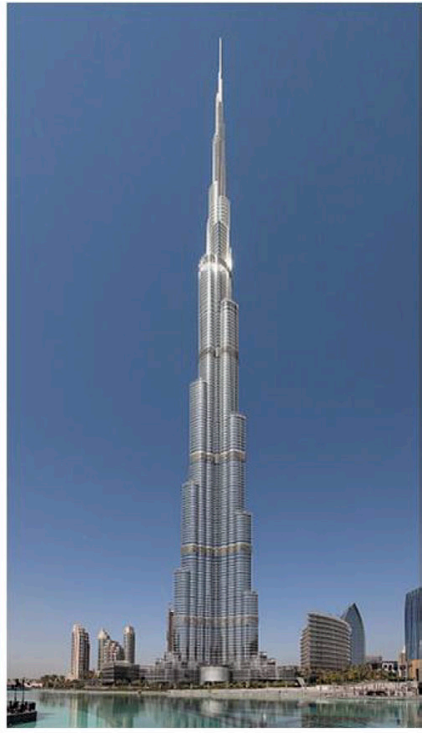

b) Burg Khalifa (828 m), 2010
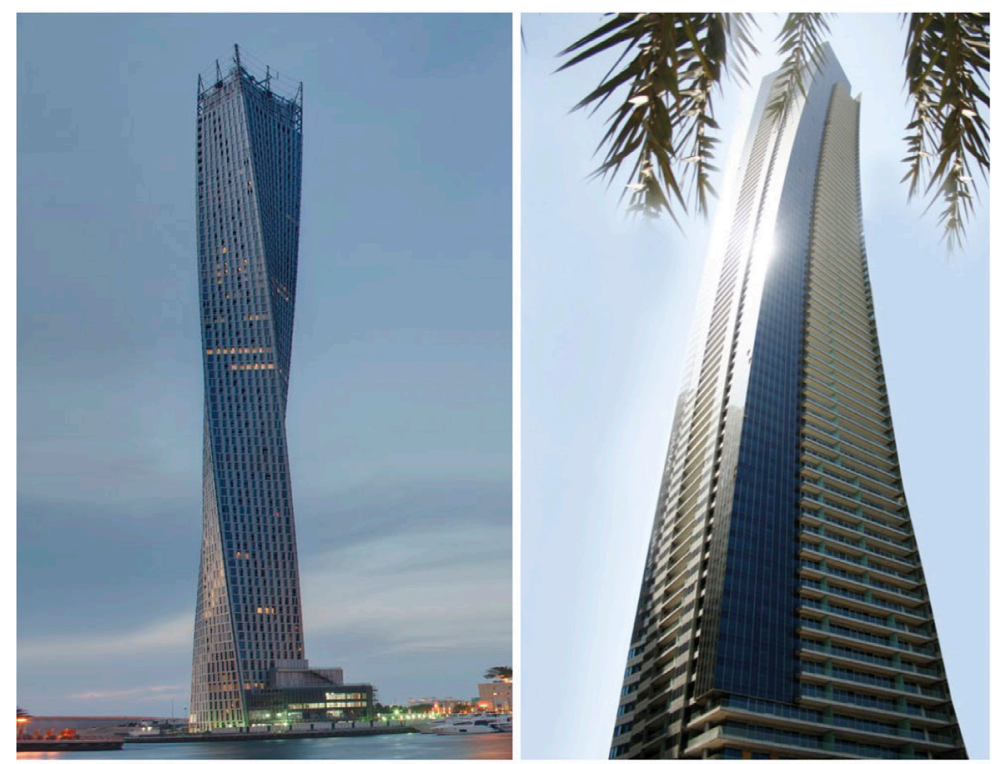

c) Cayan Tower (306 m), 2015

d) Ocean Heights (310 m), 2010

Figure 31: High rise buildings in Dubai. 


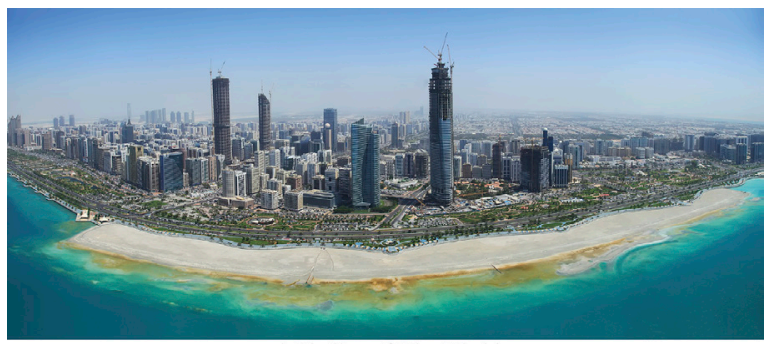

a) Skyline of Abu Dhabi

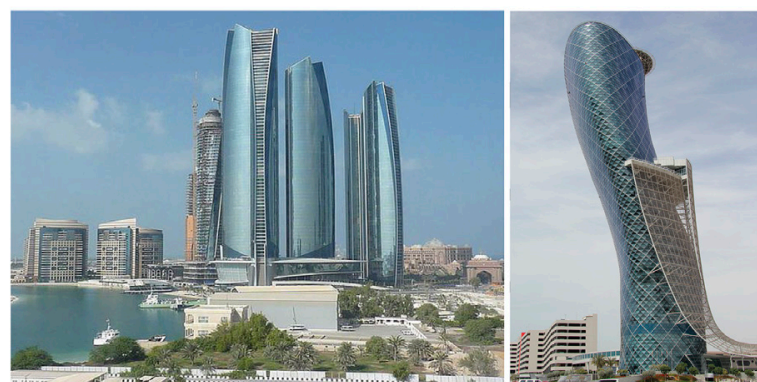

b) Etihad Towers $(277 \mathrm{~m}), 2011$

c) Capital Gate $(160 \mathrm{~m}), 2011$

Figure 32: High rise buildings in Abu Dhabi.

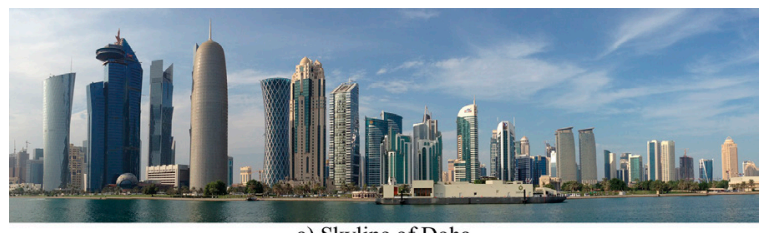

a) Skyline of Doha

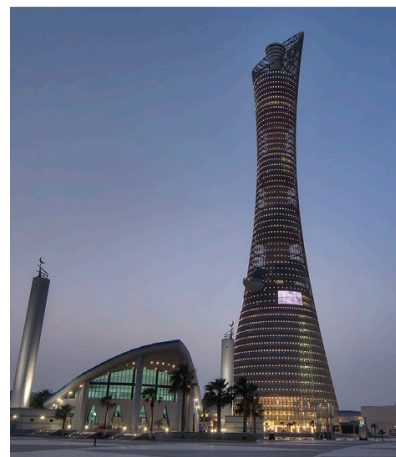

b) Aspire tower ( $300 \mathrm{~m}), 2007$

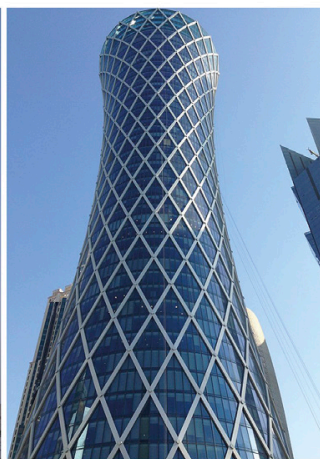

c) Tornado Tower $(195 \mathrm{~m}), 2008$

Figure 33: High rise buildings in Qatar. 

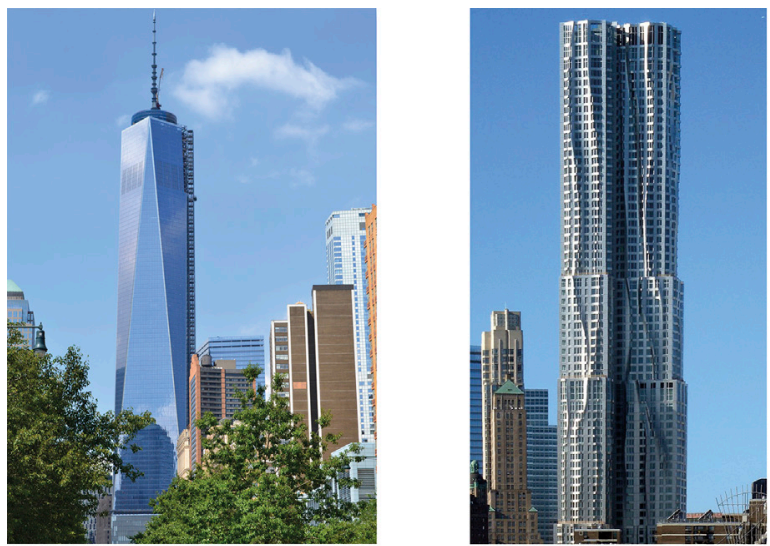

a) Bank of America Tower (366 m), 2019

b) Beekman Tower (265 m), 2011

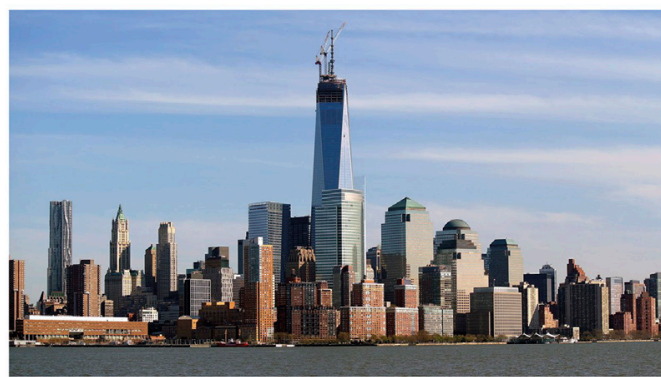

c) One World Trade Centre (541 m) 2014

Figure 34: New high rise buildings in New York.

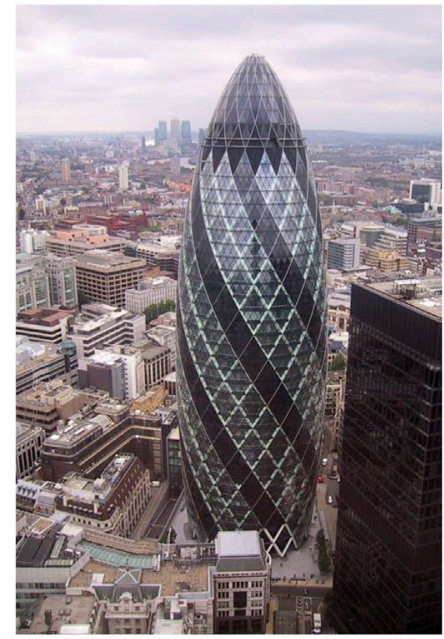

a) Swiss Re building (180 m), 2013

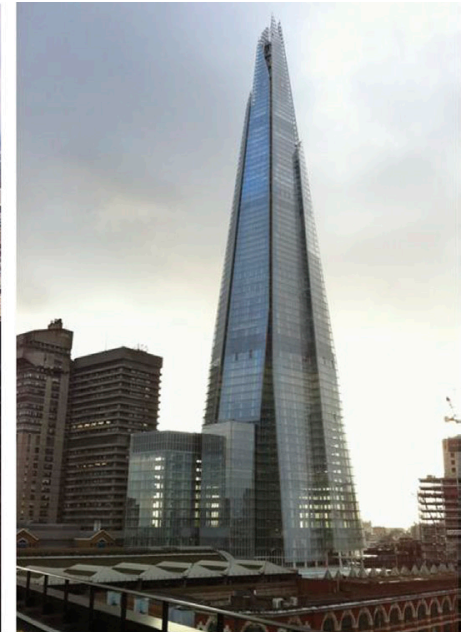

b) The Shard (306 m), 2014

Figure 35: New high rise buildings in London. 


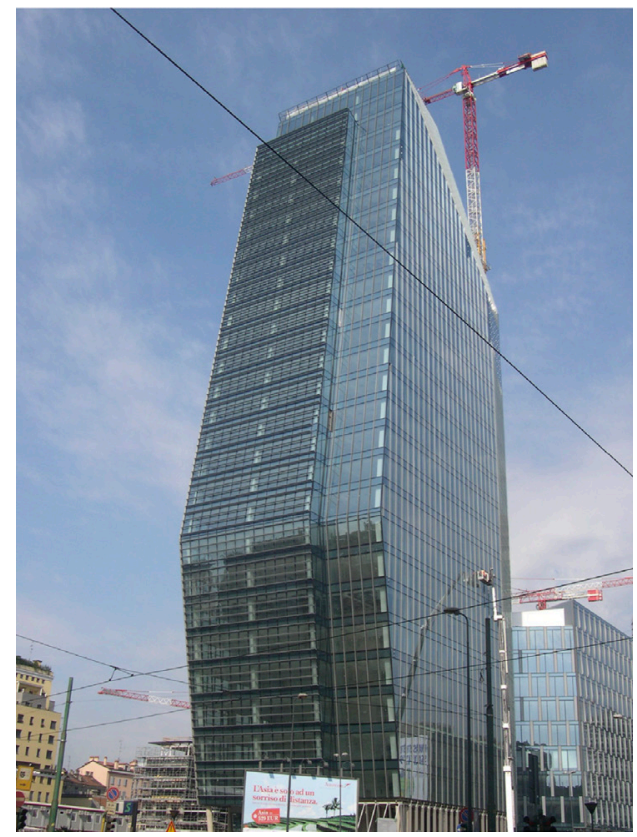

Figure 36: Diamond Tower, Milan (140 m), 2012.

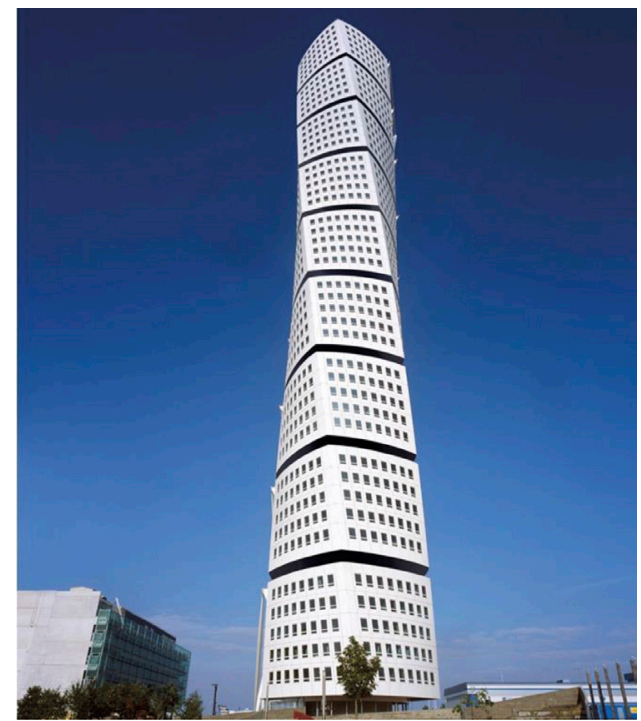

Figure 37: Turning Torso, Malmoe (190 m), 2005. 
Water Tower) whose horizontal cross section resembles a raindrop. All are presented in Figures 38 to 41 .

Other Spanish cities such as Bilbao or Zaragoza have incorporated new iconic buildings in recent years. In the former case, the Guggenheim Museum provided the opportunity to create an unusual design and in the latter case a World Exhibition gave way for several architectural concepts and amongst them the one coined the Torre del Agua (The Water Tower) whose horizontal cross-section resembles a raindrop.

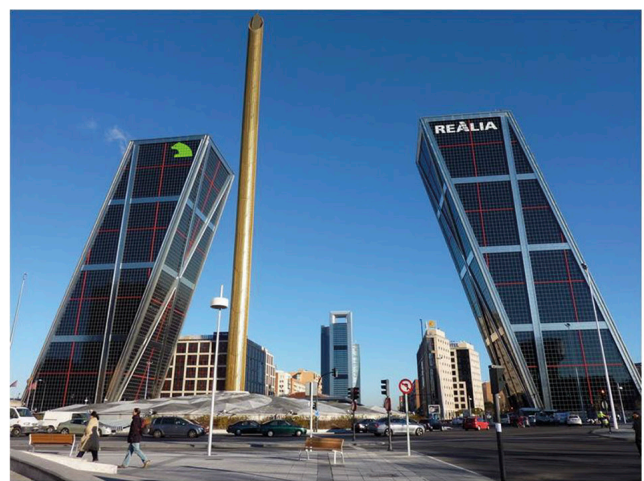

a) Puerta de Europa building (114 m), 1996

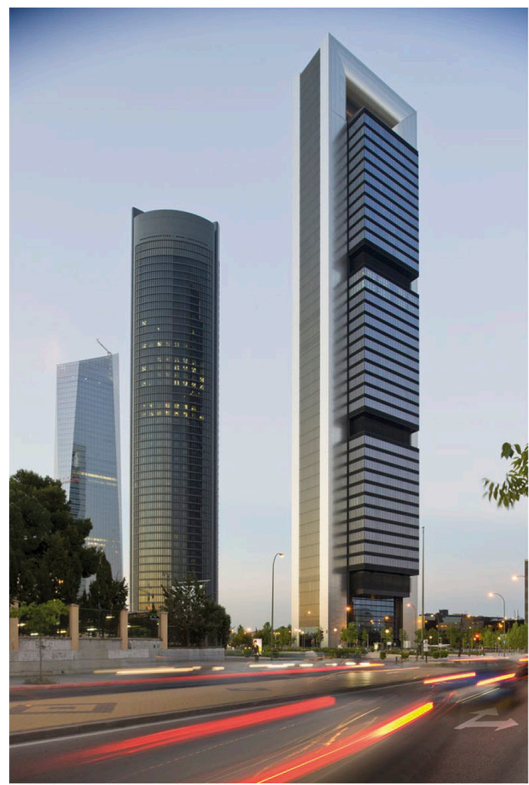

c) Vallehermoso (left) and Repsol (right) Towers, 2008

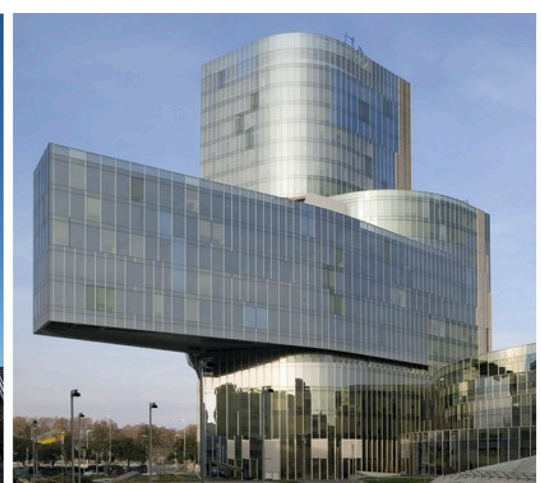

b) Gas Natural headquarters (306 m), 2014

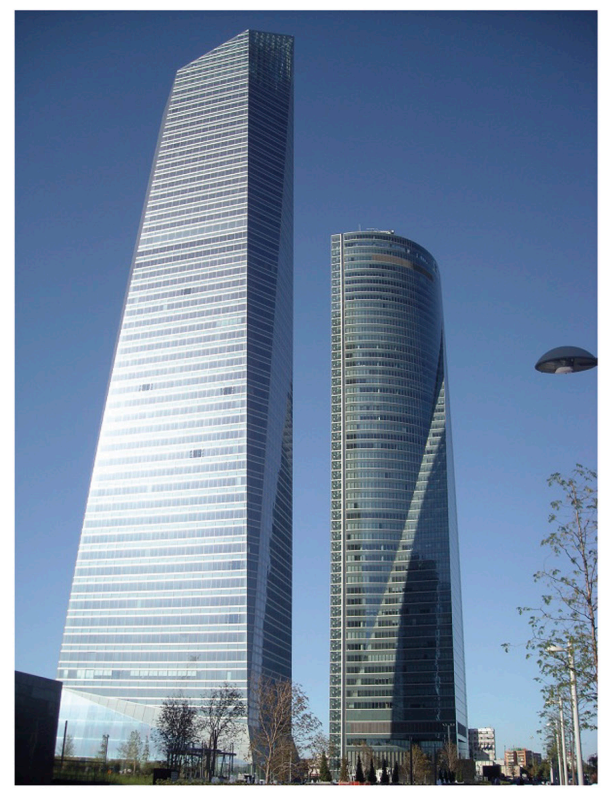

d) Mutua Madrileña (left) and Espacio (right) Towers, 2008

Figure 38: Innovative buildings in Madrid (Spain). 


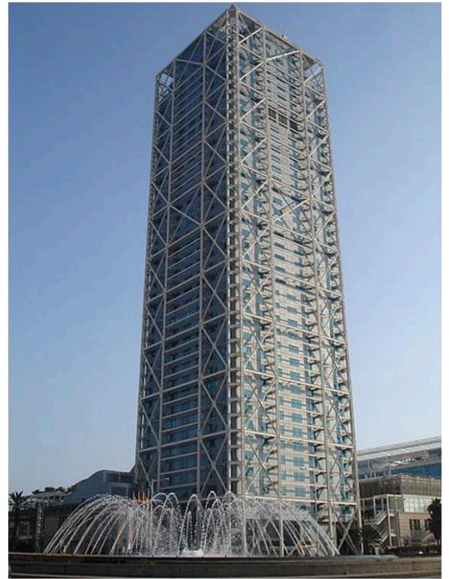

a) Hotel des Arts (150 m), 2004

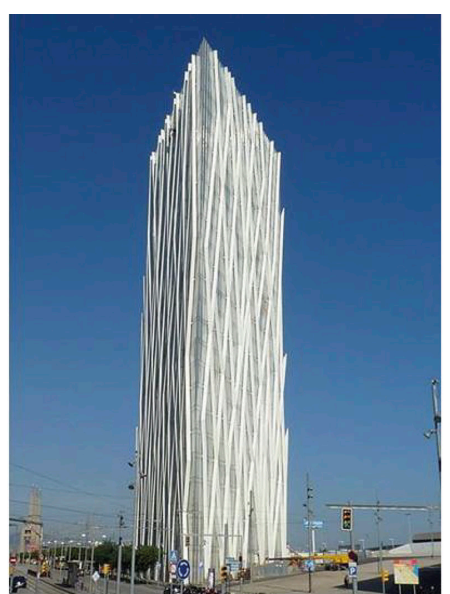

b) Telefonica Tower (110 m), 2011

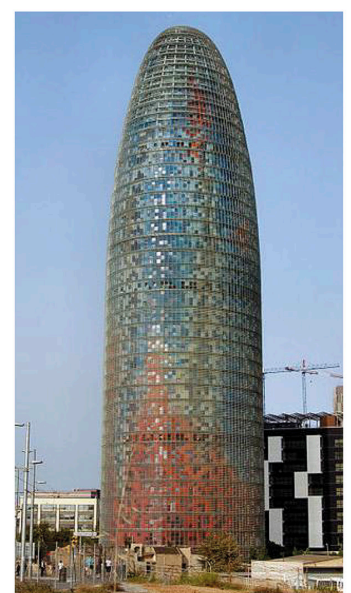

c) Agbar Tower (145 m), 2004

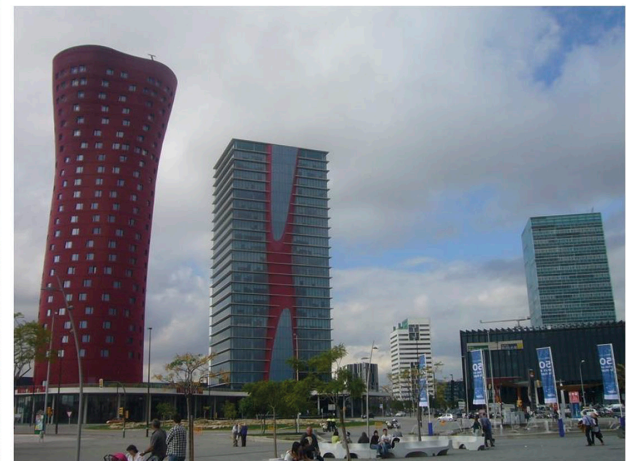

d) Togo and Ito towers, Hospitalet (113 m), 2010

Figure 39: Innovate buildings in Barcelona area (Spain).

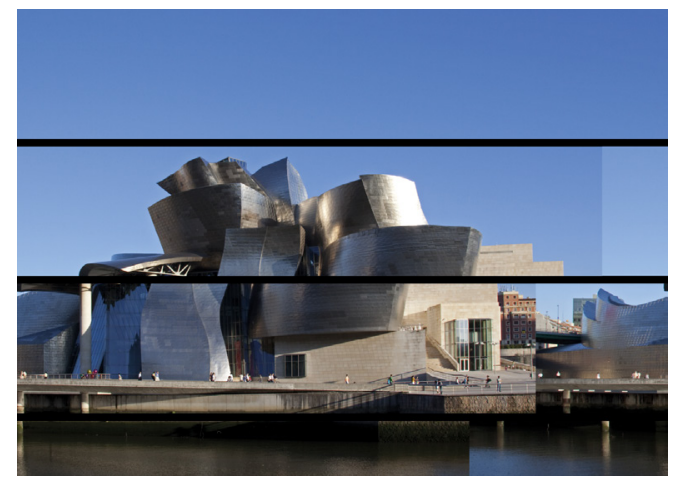

Figure 40: Guggenheim Museum, 1997, Bilbao. 


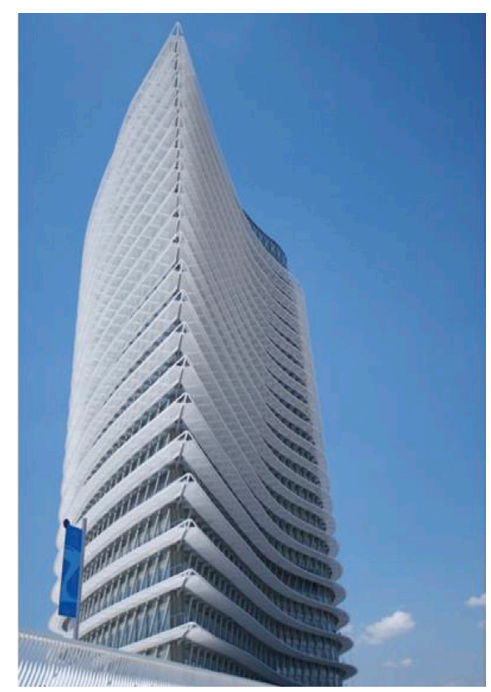

Figure 41: The Water Tower, 2008, Zaragoza.

\section{CONCLUSIONS}

Some conclusions can be extracted from the information presented:

1. Long and ultra long span bridges, whether suspensión or cable-stayed structures, have achieved a high level of excellence and safety and are being used in several locations to cross wide geographical features. By linking different islands in an Archipelago or crossing challenging estuaries they are, to some extent, recreating the shape of our planet and this process is going to continue in the near future.

2. High rise buildings have flourished everywhere since a few decades ago at a increasing rate. Half of the existing tall buildings have being erected in the last 10 years. No unique aesthetic canon may define the style of these constructions in recent years. There are many differences in shape, proportions, external appearance and thus, a diversity or eclecticisme that allows the designers to carry out their proposals in a creative way.

\section{REFERENCES}

[1] Blockley, D., Bridges, the Science at of the World's Most Inspiring Structures, Oxford University Press, New York, 2010.

[2] Graf, B., Bridges That Changed the World, Prestel, Munich, 2005.

[3] Billington, D.P., The Tower and the Bridge, The New Art of Structural Engineering, Princeton University Press, Princeton, 1983.

[4] Heinly, E. \& Leonhardt, F., Torri, Arnaldo Mondadori Arte, Milano, 1990.

[5] Escrig, F., Towers and Domes, Computational Mechanics Publications, Southampton, 1998.

[6] Hernandez, S., The Rías altas link: a challenging crossing, Strait Crossing 2001, ed. J. Krokebord, Balkema Publishers, pp. 407-414, Lisse, 2001.

[7] Simiu, E. \& Scanlan, R.H., Wind Effects on Structures, John Wiley, New York, 1996. 
[8] Gimsing, N.J., Cable Supported Bridges. Concept \& Design, John Wiley, New York, 1997.

[9] Jurado, J.A., Hernandez, S., Nieto, F. \& Mosquera, A., Bridge Aeroelasticity. Sensitivity Analysis and Optimal Design, WIT Press, Southampton, 2011.

[10] Svensson, H., Cable-Stayed Bridges. 40 Years of Experience Worldwide, Ernst \& Sohn, GmbH and Co. KG, Weinheim, 2012.

[11] Wright, F.L., A Testament, Horizon Press, New York, 1957. 